\title{
Imitation and contemporaneity: Kierkegaard and the imitation of Christ
}

Joshua Cockayne, The Logos Institute for Analytic and Exegetical Theology, Department of Divinity, University of St. Andrews.

\section{Introduction}

What it is the purpose of the Christian spiritual life? One prominent answer to this question which has been discussed repeatedly in Christian theology, is that the Christian ought to be an imitator of Christ. And when one thinks of the theology surrounding imitation, one perhaps thinks of writers such as Thomas à Kempis, St Francis of Assisi, St Augustine, and Dietrich Bonhoeffer. Yet, when one considers the contribution of the $19^{\text {th }}$ century Danish philosopher Søren Kierkegaard to Christian spirituality, the theology of imitation does not immediately spring to mind. However, Kierkegaard has a great deal to contribute to our understanding of what it means to imitate Christ, and this is a theme which he devotes a great deal of time to, particularly in the latter period of his authorship. In this paper, I will give an overview of Kierkegaard's discussion of imitating Christ which, I hope, can both bring clarity to this aspect of Kierkegaard's thought, as well illuminating what it means for a believer to be an imitator of Christ.

The theme of imitating Christ is something which pervades Kierkegaard's writings. As Howard and Edna Hong note, it is a particularly prominent theme in the second half of his authorship (1847-1855), which, they claim, 'is marked by a heightened level of ideality in the requirement of imitatio Christi' (1998, xxii). ${ }^{1}$ In this later period of Kierkegaard's writings, imitating Christ is described as one of the distinctive marks of the 'true Christian'. For instance, in Judge For Yourself!, Kierkegaard writes that

[i] mitation, the imitation of Christ, is really the point from which the human race shrinks. The main difficulty lies here; here is where it is really decided whether or not one is willing to accept Christianity. If there is emphasis on this point, the stronger the emphasis the fewer the Christians. If there is a scaling down at this point (so that Christianity becomes, intellectually, a doctrine), more people enter into Christianity. If it is abolished completely (so that Christianity becomes, existentially, as easy as mythology and poetry and imitation an exaggeration, a ludicrous exaggeration), then Christianity spreads to such a degree that Christendom and the world are almost indistinguishable, or all become Christians; Christianity has completely conquered - that is, it is abolished! (FSE, 188; emphasis in the original) ${ }^{2}$

Kierkegaard claims that true Christianity is forfeited when one gives up on, or scales down, the task of imitating Christ. The result of this scaling down is that a person's actions are unimportant or irrelevant to their being a Christian. 'To be a Christian' of this kind, Kierkegaard writes, can be combined easily with being a thief or an adulterer-this is a 'woblfiel [cheap] edition of what it is to be a Christian' (FSE, 189). The difference between the cheap Christian and the true Christian, then, lies in the individual's imitation of Christ.

Similarly, we see the claim that imitation is the distinctive mark of true Christianity argued for in the earlier Practice in Christianity, which is written under the pseudonym 'AntiClimacus. ${ }^{3}$ Anti-Climacus tells us that "the admirer" is still not a true Christian... [o]nly the imitator is the true Christian' (PC, 256). Again, it is the imitation of Christ which distinguishes true Christianity from its counterfeit. Here, it is the distinction between 'admirer' and 'imitator' 
which helps to distinguish between true and counterfeit Christianity. He introduces this distinction in his opening prayer to the discussion of imitation in Chapter IV of Part III: ${ }^{4}$

Lord Jesus Christ, you did not come to the world to be served and thus not to be admired either, or in that sense worshipped. You yourself were the way and the life-and you have asked only for imitators. If we have dozed off into this infatuation, wake us up, rescue us from this error of wanting to admire or adorningly admire you instead of wanting to follow you and be like you. (PC, 234; emphasis in the original)

According to Anti-Climacus, the difference between the admirer and the imitator is that the admirer stands at a personal distance from the person he admires and does not realise that what he admires 'involves a claim upon him, to be or at least to strive to be what is admired' (PC, 241). Contrastingly, the imitator 'is or strives to be what he admires' (PC, 241). Because of this difference, the admirer is interested only in the greatness of Christ and is unconcerned with Christ's suffering and humility since this would require him too to suffer (PC, 245-6). In truly imitating Christ, Anti-Climacus goes on to say, we imitate not his loftiness or his greatness, but his abasement (PC, 259). The imitator must strive to be like Christ not just when it is in her own interest, but also, in their struggle with God's will, in their obedience to death and their willingness to become nothing.

Whilst it is uncontentious that, for Kierkegaard, the believer's imitation of Christ is an essential aspect of Christian her faith, what is less clear is precisely how we should interpret Kierkegaard on this issue. Whilst there are some existing interpretations in the literature, ${ }^{5}$ there is not always an agreement on what Kierkegaard intends to convey. Here, I will bring together some of the insights of the existing literature and develop my reading of Kierkegaard's account of imitation by focusing particularly on Kierkegaard's remarks concerning contemporaneity with Christ. Before developing this interpretation, I first compare what Kierkegaard writes about imitation to some existing approaches in the history of theology. In the first half of this paper, I aim to describe what is distinctive about Kierkegaard's account of imitation and how it compares to other accounts. ${ }^{6}$

\section{Christ as prototype: Kierkegaard on literalistic moralism}

To begin our comparison of Kierkegaard's theology of imitation with other historical accounts, I will focus first on a certain strand of medieval thinking which maintains that imitating Christ consists in attempting to replicate or copy the actions which Christ is recorded to have performed. ${ }^{7}$ This conception of imitation, which I will refer to as 'literalistic moralism', gained prominence in the eleventh and twelfth centuries, in which there was a shift from an early (preninth-century) ${ }^{8}$ focus on the divinity of Christ to a more literalistic focus on the historical, human Christ. This shift in focus meant that discussions of the imitation of Christ had a more moralistic focus than the earlier theological accounts. Bernard of Clairvaux (1090-1153 CE), for instance, in his second sermon on Pentecost describes Christ going through the different stages in human life to provide a model for Christian living. Writing from the perspective of Christ, Bernard writes that, Christ lived the human life so that, 'My conception may cleanse yours...In My life you may know your way, so that just as I held the unswerving paths of poverty and obedience, humility and patience, love and mercy, so you too will follow these footsteps' (Leclercq, I, 87, (trans., Constable $(1995,189)) .{ }^{9}$ In places, late eleventh-century thinking on imitation focused so literalistically on the life of Christ that '[e]very detail of His behaviour, appearance, and clothing was seen as a pattern' (Constable (1995), 180). Otloh of St Emmeram, for example, stated that Christ 'should be imitated in all things as much as possible' (from Pez (1721), II.2, (translation, Constable (1995), 180)). ${ }^{10}$ Since copying Christ's historical actions is so essential to this account, the study of the New Testament is of vital importance for imitating Christ. 
Kierkegaard borrows aspects of this moralistic tradition in his own account of imitation. He claims, in a journal entry from 1834, for instance, that 'Christ's whole life in all its aspects must supply the norm for the life of the following Christian and thus for the whole Church' (JP, (eds. Hong and Hong (1967), 273). He also repeatedly refers to Christ as the 'prototype' (PC, 245) and the one who leaves 'footprints' (PC, 238) for the Christian. ${ }^{11}$ In Judge For Yourself!, he maintains that this kind of literalistic moralism has 'a decisive advantage' over the kind of cheap Christianity of his Danish contemporaries. What contemporary religious believers miss, Kierkegaard maintains, is that the Christian is required to both act and to transform, something which is entirely lacking from cheap Christianity (FSE, 192). It is not only in general terms that Kierkegaard makes such observations concerning the moralistic tradition, he also specifically refers to thinkers from this tradition. As Jack Mulder Jr. notes, 'Bernard [...] wins praise from Kierkegaard for being a genuine pre-Reformation Christian, since at least the monastery feared secularism, but the Reformation simply ushered in "unmitigated profane secularism, worse than paganism"” (2008, 40, quoting Kierkegaard (JP 3, 2764)).

Thus, there is certainly a moralistic influence on Kierkegaard's writing concerning imitating Christ. Kierkegaard affirms the importance of imitating Christ in the way that it is emphasised by Bernard and others during the medieval period. However, whilst drawing from this tradition, he does not entirely endorse it. In contrast to moralism, Kierkegaard emphasises the distance between humanity and Christ. For instance, Kierkegaard claims that 'to be a Christian certainly does not mean to be Christ (what blasphemy!) but means to be his imitator' (PC, 106). And, whereas the moralist affirms that we can become more like Christ by imitating Christ's actions, Kierkegaard writes that imitation is always 'approximate' and 'life-long' (Stan, 2014, 206). If a person could become like Christ, as Leo Stan interprets Kierkegaard, there would be no need for Christ as a prototype, and individuals would seek to emulate other believers rather than looking to Christ himself $(2014,206-7)$. As Marie Thulstrup puts this point, for Kierkegaard, there is a 'qualitative difference' between Christ and mere men, which means that 'Christ cannot be the pattern in a literal sense of the term' (Thulstrup, 1962, 272).

Kierkegaard also critiques the view of religious authority which was often defended by those in the tradition of literalistic moralism. For instance, in a journal entry, Kierkegaard writes that,

When a man like Bernard of Clairvaux or Pascal, both of them significant characters let such a confusion go undisturbed as the Pope's calling himself Peter's successor [Eterfolger] (and thus nonsensically parodying the imitation [Efterfolgelse] of Christ), there is still the question of whether this is connected with their wanting to coddle themselves or their perhaps unconsciously and with instinctive cunning refraining from risking what would of necessity come to be martyrdom, a bloody martyrdom. (JP, 2 1930)

Although Kierkegaard commends Bernard's influence as 'significant' here, his critique of the medieval conception of imitation focuses on the authority that is given to those who imitate Christ from a position of authority. As Mulder puts it, ' $[t]$ his, according to Kierkegaard, was a principal fault of Catholicism, to imagine that humans could become perfect and like Christ, thus usurping the role that belonged only to Christ' $(2008,36)$. In giving such an emphasis to religious authority, Kierkegaard contends that the individual evades the challenge of imitating Christ directly herself. ${ }^{12}$

Finally, Kierkegaard also resists the kind of reading of Scripture which he thinks literalistic moralism endorses. For instance, whilst Christianity requires us to be compassionate as Christ was, the Christian is not required to slavishly replicate the exact circumstances in which Christ would show compassion. Kierkegaard writes that a person can will the good in 'solitary confinement, removed from all human beings' (UDVS, 144), for instance. Moralism gives too 
important a role to the historian, for Kierkegaard; instead, the individual must relate directly to God through Christ rather than historically and indirectly through the historian. Consider Kierkegaard's remarks in one of his late journal entries, for instance:

And my task is [...] to proclaim the infinite reality which each man has in himself, when he remains before God. But in this way I do not have a scrap of doctrine-and doctrine is what is wanted. For doctrine means lazy imitation for the student. (JP, XI 2 A 19 (ed. Smith $(1965,190))^{13}$

The key difference between moralism and the account of the imitation Kierkegaard endorses, then, is the nature of the relation between the individual and Christ. For the moralist, the relation to Christ is a historical one-we must understand Christ's actions as clearly as possible and replicate them. In contrast to this, for Kierkegaard, the individual relates to Christ individually and personally as a contemporary. And whilst this should still include the study of the Gospel texts, Kierkegaard writes that, '[w] hen you read God's Word, in everything you read, continually $[\ldots]$ say to yourself: It is I to whom it is speaking, it is I about whom it is speaking' (FSE, 36). For Kierkegaard, the purpose of reading Scripture is not primarily to gain historical knowledge of Christ, but rather, to relate personally to Christ and to cultivate the kind of contemporaneity which is important for imitation. I will return the importance of contemporaneity in our interpretation of imitation in the concluding section.

\section{Christ as sufferer: Kierkegaard on ascetism}

Another prominent aspect of medieval theology which Kierkegaard engages with is the ascetic understanding of imitation. The thinkers in the ascetic tradition (contrary to moralism) share Kierkegaard's conviction that we ought to stress the difference between humanity and Christ. Because of this difference, the ascetic gives an important role to self-denial and withdrawal from the world. Imitating Christ, according to the ascetic, means denying the pleasures of this world. Thus, the imitation of Christ requires a disciplined regimen of fasting, prayer and self-denial. Thomas à Kempis, for example, states that in order to imitate Christ, the Christian must '[s]trive to withdraw [her] heart from the love of visible things, and direct [her] affections to the things invisible' (1952, 27-8).

As Joel S. Rasmussen notes, 'while Kierkegaard and Thomas à Kempis are in full agreement about the importance of the imitation of Christ, they differ somewhat with regard to the precise character of authentic Christian imitation.' (2008, 294). ${ }^{14}$ Let us consider how this difference in character is manifest in Kierkegaard's works.

In some regards, Kierkegaard's views on imitation have striking similarities with ascetism, more so, perhaps, than with moralism. First, both place an emphasis on the individual's suffering in imitation. Thomas states that the Christian must experience the presence of Christ in order that she might 'suffer with Christ' (1952, 68-9). ${ }^{15}$ In similarity with Thomas, Kierkegaard states that imitating Christ involves sharing in his sufferings (1 Peter 4:13); he even uses the phrase 'to suffer for the doctrine' and 'the imitation of Christ' (FSE, 189, emphasis in the original) synonymously in places. Kierkegaard encourages a level of self-denial, describing Christianity as 'the very opposite of what is to a human being's taste and disposition' (TM, 253). Secondly, both emphasise some kind of experiential relationship with Christ. It is possible, according to Thomas, to develop a close friendship with Christ by conversing with him $(1952,77)$. Similarly, Practice in Christianity begins with the 'Invocation' which states that the believer 'must be just as contemporary with Christ's presence as his contemporaries were' (PC, 9). 
Nevertheless, despite these similarities with the ascetic tradition, Kierkegaard rejects the ascetic account of imitation in his writings. Kierkegaard's rejection of ascetic Christianity develops over the course of his authorship. In places in his writing, Kierkegaard is very critical of asceticism, however, he appears to change his mind in his later writings (particularly in his writings post 1848). In Works of Love (1847), for instance, Kierkegaard writes that

compared with true Christian inwardness, the cloister's hiding place in the solitude of the forest or far away on an inaccessible mountaintop and the silent inhabitant's hiding place in the cloister are childishness [...] Through a similar misunderstanding of Christianity, through a similar piece of childishness, people thought that it was Christian to betray the secret, to express in a worldly way Christianity's indifference to friendship, to family relationships, to love of the fatherland-which is indeed false, because Christianity is not indifferent in a worldly way to anything; on the contrary, it is concerned about everything simply and solely in a spiritual way. (WL, 144)

Likewise, in the Postscript (1846), the pseudonymous author Johannes Climacus writes that '[t]he monastic movement wants to express interiority by outwardness that is supposed to be interiority [...] But a truly pathos-filled existing person will every moment express for himself that the absolute is the absolute' (CUP, 409). To take off the finitude of existing as a human being and to 'put on the abstract attire of the monastery' (CUP, 410) is to cease to be human in some way. Based on this evidence alone, it would appear that Kierkegaard has no affinity with asceticism.

However, as I have stated previously, the most detailed accounts of imitation in Kierkegaard's writings are found later than both of these critiques of asceticism. And in the later writings, we find a different response to asceticism. Kierkegaard appears to soften to some of the aspects of the ascetic tradition later in his authorship. In part, as Rasmussen argues, this softening to asceticism can be accounted for by Kierkegaard's acquiring a Danish translation of Thomas's The Imitation of Christ in 1848 (2008, 291). Although Kierkegaard makes no reference to Thomas in his published works, it is apparent that the theme of imitation plays a much more crucial role post 1848 (Rasmussen, 2008, 291).16 For instance, in contrast to the remarks in Works of Love and the Postscript, in a journal entry from 1854, Kierkegaard writes,

It is a special sort of a retreat we should make. Back to the monastery-the question must be brought back to the monastery from which Luther broke out (this is probably the truth) $[\ldots .$.$] The monastery's error was not asceticism, celibacy, etc. No, the error was that$ Christianity was reduced by allowing this to be regarded as pertaining to extraordinary Christians - and then all the purely secular nonsense as ordinary Christianity. No, asceticism and everything belonging to it is merely a beginning, a condition for being able to be a witness to the truth. Therefore the swing Luther made was in the wrong direction [...] Consequently the error in the Middle Ages was not the monastery and asceticism but that basically the secular mentality had conquered in the monk's parading as the extraordinary Christian. (JP 3:215)

As well as this being an extraordinary shift in perspective on the value of ascetism, what Kierkegaard draws attention to in this passage is, I think, the very point he makes in Judge For Yourself!, that the ascetics were correct in their emphasis on the actions and behaviour of individuals. As Rassmussen puts it, "for Kierkegaard, the merit of the imitatio Christi tradition in general, and presumably of Thomas à Kempis in particular, is the emphasis placed on the 
dimension of "action, life, existence-transformation" that he thinks the Christians of his era neglect' $(2008,295)$.

However, despite this praising of aspects of asceticism and the shift in Kierkegaard's later writings, it would be misleading to regard Kierkegaard as endorsing ascetic views on imitation. For instance, in Judge For Yourself! (1851-2, posthumously published in 1876), Kierkegaard writes that the 'monastic-ascetic Christianity' of the Middle Ages, made the monastery the mark of the true Christian and thus took the emphasis away from the individual and her relation to God (JFY, 195). He also writes that it is 'strange' that the monastic-ascetic thinkers

could think that in itself fasting was Christianity, that entering the monastery, giving everything to the poor, not to mention what we can scarcely mention without smilingscourging oneself, crawling on one's knees, standing on one leg, etc.—that this was supposed to be imitation. This was an error. (JFY, 192)

The error which Kierkegaard draws attention to here is the lack of a theology of grace in the ascetic's thinking; the error is to assume that one can earn merit before God by striving to imitate Christ. Whilst the medieval theologians were right to place a strong emphasis on the fact that imitation requires specific actions and works from the Christian, Kierkegaard rejects the ascetics because they turn imitation into merit (JFY, 192). In contrast to this, for Kierkegaard, the Christian life must be characterised by the reception of God's grace (FSE, 17). Like Thomas, Kierkegaard claims that imitation requires an individual to draw near to Christ through the experience of Christ's presence, yet unlike Thomas, the purpose of this experience is that a person comes to know the value of God's grace.

The point of contrast between Kierkegaard and Thomas, is that imitation is not about merit, but about grace. As he writes in the opening of For-Self-Examination, 'Christianity's requirement is this: your life should express works as strenuously as possible; then one more thing is required - that you humble yourself and confess: But my being saved is nevertheless grace' (FSE, 17). The crucial difference between the ascetic view of imitation and Kierkegaard's view, as Rasmussen puts it, is that for Kierkegaard, 'when the recognition of one's need for grace derives from striving to imitate Christ and falling short of the ideal, then one is all the more appreciative of God's forgiveness; whereas "as soon as imitation is completely omitted, grace is taken in vain"” $(2008,295)$.

\section{Christ as one to be admired: Kierkegaard on Danish-Lutheranism}

Let us consider one further comparison that Kierkegaard makes in his writings. In Judge for Yourself!, Kierkegaard positions himself somewhere between 'monastic-ascetic Christianity' and the theology of his contemporaries in the nineteenth-century Danish Lutheran Church. For Kierkegaard, just as the ascetic makes the mark of the true Christian the monk, those of his own time place too much importance on the role of the professor. He claims that,

just as in the Middle Ages not all entered the monastery, but all stood in relation to the monastery and saw the true Christian in one who entered it, so in our day all stand in relation to the professor - the professor is the true Christian. (FSE, 195)

The 'professional-scholarly Christianity' (FSE, 195) of nineteenth-century Danish Lutheranism which Kierkegaard wishes to distance himself from here, can be seen as a development of the 
Lutheran rejection of Catholic theology. It is the established figures of the Danish Church and not Luther that Kierkegaard is interested in critiquing here, however, as he presents it in Judge for Youself!, we can trace the nineteenth-century views on imitation (or rather, lack of) back to the Reformation. As Kierkegaard presents this development: 'Luther appears' (FSE, 192) and declares that those in the Catholic tradition wrongly promote salvation by works by protesting: 'in God's name, to hell with the pope and all his helpers' helpers, and away with the monastery, together with all your fasting, scourging and all the monkey antics that came into use under the name of imitation' (FSE, 193). Kierkegaard tells us here that Luther did not aim to abolish imitation, but rather, he 'affirmed imitation in the direction of witnessing to the truth' (FSE, 193). So, whilst Kierkegaard affirms that Luther was correct to react against the salvation by works which the moralistic and ascetic traditions defended, the Church that subsequently develops in the Lutheran tradition misses the point. Because of Luther's emphasis on grace, Kierkegaard claims, later generations have a 'slackened' (FSE, 193) view of imitation and Christian action. Subsequently, many generations on from Luther, the task of becoming a Christian has become too easy (FSE, 193). As he describes the Christian culture of his own time:

perhaps one hears a little about something that perhaps is Christianity; one reads a little, thinks a little about Christianity, experiences a mood once in a while-and then one is a believer and a Christian. Indeed, one is already one in advance; one is born a Christian. (FSE, 194)

This kind of Christianity, Kierkegaard claims, bears little resemblance to the Christianity defended by Luther. When we start with the assumption that everyone is a Christian by birth, then Christianity becomes the assumed belief in the culture and, to use an example from the Postscript, one assumes that one is a Christian simply because one is a Danish civil servant (CUP, 50-1). From this culture in which Christianity is the accepted norm, Kierkegaard goes on to say, we see the emergence of 'professional-scholarly Christianity' (FSE, 195) in which Christianity is no longer about the individual and her relation to God, but is a profession and an academic discipline. Under this kind of understanding of Christianity, Kierkegaard maintains, 'Faith does not exist...Imitation is an impossibility...The "professor" cannot fasten down anything; what he can do is put everything in abeyance' (FSE, 196).

\section{Kierkegaard on imitation: contemporaneity and presence}

Although we have seen how Kierkegaard critiques other accounts of imitating Christ, it is not yet clear what he endorses as an alternative. We are thus left with a puzzling question: How can a person consistently seek to imitate Christ without either endorsing moralism or cheapening grace? Kierkegaard has a clear and consistent answer to this question. A person must relate to Christ as a contemporary. It is the condition of 'contemporaneity' with Christ which is the crucial piece of the puzzle for understanding Kierkegaard's account of imitation. ${ }^{17}$ However, this is a notoriously difficult concept to understand in Kierkegaard's writings. Although there is clearly not scope here for a detailed analysis, in this section, I will offer some brief remarks which can illuminate our understanding of imitation through contemporaneity.

As with the discussion of imitation in Kierkegaard's writings, the theme of being contemporary with Christ is a concept which pervades Kierkegaard's authorship. In a number of places, Kierkegaard claims that Christian faith requires an individual to relate to Christ not historically, but rather, as a contemporary (PF, 69). One of the most detailed discussions of this concept is found in Practice in Christianity. It is no accident, I think, that in Practice in Christianity we 
find the most extended discussion both of imitation as well as of contemporaneity- the two are clearly connected. The text begins with a reflection on the believer's relation to Christ. AntiClimacus writes that

It is indeed eighteen hundred years since Jesus Christ walked here on earth, but this is certainly not an event like other events, which once they are over pass into history and then, as the distant past, pass into oblivion. No, his presence here on earth never becomes a thing of the past [...] contemporaneity is the condition of faith, and, more sharply defined, it is faith. Lord Jesus Christ, would that we, too, might become contemporary with you in this way, might see you in your true form and in the surroundings of actuality as you walked here on earth. (PC, 9)

It is in approaching Christ as a contemporary, that a person is able to avoid the error of relating only to Christ in historicity at a distance and thereby only admire him. As Anti-Climacus describes it here, an individual can approach Christ as contemporary by experiencing Christ's presence. Thus, there appears to be something experiential about a person's relationship to Christ. Furthermore, this experience of Christ's presence is closely related to the discussion on imitation; Anti-Climacus urges the reader to become contemporary with Christ in his abasement' (PC, 172). The relevance of this should be obvious - it is Christ's abasement that the individual should seek to imitate, as we have previously seen (PC, 238). We can see this connection made elsewhere. As Kierkegaard writes in an 1848 journal entry, relating to Christ as a contemporary is the means of imitating Christ and receiving God's grace:

By becoming contemporary with Christ (the exemplar), you discover precisely that you don't resemble it at all [...] From this it follows, then, that you really and truly learn what it is to take refuge in grace (NB6:3 (ed. Cappelørn et al., 2011,9)).

The condition of being contemporary with Christ is how we are to understand what it is to submit to God and thereby come to imitate Christ.

However, it seems pertinent to ask just what Kierkegaard means by this: How can a person enjoy contemporaneity with an individual who existed more than two thousand years ago? There are some competing interpretations of what Kierkegaard means by 'contemporaneity' in the secondary literature which can help us respond to this question. For instance, C. Stephen Evans, in explaining the notion of contemporaneity in Philosophical Fragments states that, for Johannes Climacus, 'faith is the result of a first-person encounter with Christ' (1992, 115). Evans argues that contemporaneity should be understood as a kind of mystical experience of Christ. Similarly, Bradley R. Dewey, in extending Kierkegaard's account of contemporaneity across the whole authorship (rather than just focusing on Fragments as Evans does), writes that 'there is the clear impression of a mystical fellowship or communion with the once dead and now risen Jesus of Nazareth' $(1968,138)$ in Kierkegaard's use of the term. For Dewey, the experiential aspect of Kierkegaard's account of imitation is very different from the mysticism of Thomas à Kempis, but it is still importantly an experience of Christ's presence. Dewey describes Kierkegaard's account of the experience of contemporaneity as a life in the presence' (Dewey 1968, 126). For Dewey, it is important that the 'practice of the presence of Jesus [...] increasingly conforms [a person's] life to the pattern, the authentic spirit of Jesus becomes progressively embodied in his life' $(1968,139)$.

In contrast to the mystical or experiential readings of contemporaneity, there are those that defend a kind of 'epistemic contemporaneity'. Merold Westphal, in a chapter discussing 
Practice in Christianity, claims that '[i]t would be a mistake to think that when Anti-Climacus speaks of faith as a mode of contemporaneity with Christ he has something mystical in mind. It is rather an epistemic contemporaneity of which he speaks' $(2014,257)$. Westphal rejects the idea that being contemporary with Christ requires the individual to actually experience Christ, but rather, '[w] hat faith affirms about Jesus', he argues, 'was not "directly perceptible" then, nor is it now' (2014, 257). This line of thought, that the individual need not actually experience Christ in a mystical way to be contemporary with him, is also developed by Patrick Stokes, who argues that the best way of understanding what Kierkegaard means by 'presence' is as a certain mode of cognition which allows the believer to become contemporary with the historical Christ (rather than experience the living Christ). He claims that 'certain modes of thought have the power to negate the historical distance between contemplator and contemplated, making them, in some sense, actually present with the object' $(2010,305)$. This kind of 'experience-as' should not, however, be confused with a metaphorical sense of presence, but nor should it be understood in the mystical terms which Evans describes. Instead, Stokes argues, contemporaneity is best understood as 'an immediately self-reflexive mode of vision, i.e. one in which we apprehend our relation to what is imagined within the imaginative experience' (2010, 314). Being contemporary with Christ's teaching at the Sermon on the Mount, for instance, is a psychological phenomenon in which the individual is present with Christ in the sense that 'I experience it as addressed directly to me as much as to the contemporaries' (2010, 314). This is in keeping, Stokes argues, with Kierkegaard's discussion of Scripture in For Self Examination. Here, Kierkegaard writes that when Scripture asks something of us it is 'as if it is God himself who asked me' (FSE, 310). ${ }^{18}$

As I will show shortly, there is enough evidence from Practice in Christianity alone for us to gather a relevant account of contemporaneity for our purposes here. To see this, I will consider how we might resist a proposal such as Stokes's, which will highlight precisely what AntiClimacus means by 'contemporaneity' in its context within Practice. As I have argued in detail elsewhere (Cockayne, 2017), Stokes's proposal for how to best interpret contemporaneity across the authorship is not entirely successful. What Stokes misses, I argue, is that, for Kierkegaard, Christ is not a historical person whom we need to imagine, but rather, a living person who is supernaturally present to his believer's through his presence $(2017,55-60)$. I motivate this claim by appealing to Kierkegaard's commitment to the Lutheran doctrine of Christ's true presence in the Eucharist, and it is clear from a more detailed look at what Kierkegaard writes in his 'Communion Discourses' that this is the case. For instance, Kierkegaard writes, '[a]t the Communion table the point above all is to hear his voice. Certainly, a sermon should also bear witness to him, proclaim his word and his teaching, but a sermon is still not his voice.' (CD, 271). In taking these factors into consideration, I argue that the kind of imaginative experiences Stokes has in mind insufficiently capture what it is for living persons to engage with one another (2017, 55-57). Since Kierkegaard is clearly committed to thinking of the relation between the believer and Christ as a relation between two living persons, Stokes's account of imaginative copresence will not capture what Kierkegaard has in mind by contemporaneity with Christ.

Although I think it is possible to extend this argument to the use of contemporaneity across Kierkegaard's entire authorship, the discussion can be restricted more narrowly for the purposes of this paper. Indeed, in Practice in Christianity, Anti-Climacus connects the discussion of contemporaneity to the practice of Communion. In the context of Communion, he writes that 
[t]oday he is indeed with you as if he were closer to the earth; he is as if touching the earth; he is present at the altar when you are seeking him; he is present there- but only in order once again from on high to draw you to himself. (PC, 156)

The reason that this commits us to thinking of contemporaneity in experiential terms, as I show elsewhere (2017, 50-54), is that Kierkegaard is echoing the Lutheran doctrine of true presence in his discussion of communion. Luther contends, contrary to the Catholic tradition, that Christ's presence in the Eucharist is not corporeal, that is, he is not present in the elements $(1527 / 1961$, 56). However, neither is it merely memorialist or symbolic, but rather, Christ must be present to an individual when she receives Communion (Luther, 1527/1961, 69). It is clear that Kierkegaard is espousing an orthodox Lutheran view of the Eucharist in Practice in Christianity (as well as further afield). This point is made by George Pattison, who describes Kierkegaard's view of Communion as involving 'concrete encounter [...] with the person of Jesus Christ' (2012, 160).

Let us consider the relevance of this for our understanding of contemporaneity and imitation. If Anti-Climacus is emphasising the importance of the believer's experience of Christ's presence at the Communion table in a way that is more than symbolic, then it would be strange for his earlier comments concerning Christ being contemporary with believers by his presence to be only imaginative in the way that Stokes describes. Kierkegaard clearly regards Christ as a living person whom the individual can draw close to by experiencing his presence. Thus, the experience of being contemporary with Christ should be understood in these terms also.

We can see this point without casting the discussion any wider than how it occurs in Practice in Christianity. Thus, if contemporaneity depends on a person's experiencing Christ's presence, and being contemporary with Christ is essential for their imitation of Christ, then we can see that the experience of Christ's presence is also essential for imitating Christ. However, what the preceding discussion helps to clarify is just how a person can submit to God in the way that Kierkegaard describes it. And although this might eventually culminate in a person's suffering and martyrdom, it is the submission to God through an experience of Christ's presence which is primary for a person's imitation of Christ and not the human striving towards suffering or martyrdom.

Going beyond the concepts which Kierkegaard uses himself, we can further elucidate this account of imitation. More specifically, the connection between the experience of Christ's presence and the imitation of Christ forms the basis of a kind of conversion experience. ${ }^{19} \mathrm{~A}$ person's experience of Christ, made possible through the practices of Church, allows her to undergo personal transformation. As Andrew Torrance puts this point,

For Kierkegaard, the question of what it means to become a Christian cannot be separated from the question of what it means to live out a Christian life. Why is a discussion of Christian practice so critical? Kierkegaard understands that a person does not suddenly become a Christian, in a complete sense, either by a miraculous event or a heroic act of human freedom. Rather, Christian conversion involves a formative process of becoming that requires an ongoing commitment to following Christ. Faith is 'a task for a whole lifetime', which will never be complete. What Kierkegaard has in view, however, is not a progressive journey of spiritual self- discovery, self-understanding or self-denial a journey on which an individual's new life is built from or develops out of the old. Rather, it is conceived as a transformative journey which is grounded in loving relationship with the God who is not only present with us but also encounters us in Jesus 
Christ. It involves a growing in one's love for God that is the antithesis of any selfinitiated reflection on the mystery of the eternal beyond. It takes place, quite simply, in and through encountering Jesus Christ within the history of this world. And, in this history, particular human subjects are required to respond decisively and actively to the love of God. $(2016,117)$

As Torrance draws attention to, for Kierkegaard, the process of conversion is a lifelong event in which a person is gradually transformed by the power of Christ's spirit. Imitation, on this account is the process of Christian discipleship. By engaging with the living presence of Christ, a person can be directed to their flaws and need for repentance, she can be urged to pursue the gifts of the spirit, and seek to re-orientate her proud human will to conform to will the good. All of this is part of the process of imitating Christ. On Kierkegaard's account of lifelong conversion, to borrow from Torrance's reading, imitating Christ is not a means of achieving God's favour, but rather, imitation follows from the experience of grace $(2016,131)$. As we have seen, it is through a concrete encounter with the living Christ that this process is possible. Furthermore, one of the crucial ways of engaging with Christ in this way is through the liturgical practice of Communion.

\section{Conclusion}

For Kierkegaard, imitating Christ is the mark of the true Christian. It is through her imitation of Christ that the individual shares in Christ's sufferings, and encounters Christ in his abasement. This requires a person to act and to change, something which medieval theologians grasped far better than those in nineteenth-century Christendom, Kierkegaard thought. However, this action, of imitating the person of Christ cannot be boiled down to a literalistic moralism nor an ascetic mysticism. The purpose of contemporaneity is the realisation that we do not resemble Christ and that we are truly in need of grace. The opposing extreme which Kierkegaard wishes to distance himself from, a kind of Danish-Lutheran academic Christianity, makes the mark of the true Christian he who has the greatest knowledge of history, philosophy, and Scripture. The scholar-Christian is as destructive to true-Christianity as the ascetic-Christian, according to Kierkegaard. True imitation, for Kierkegaard, must be a response to God's grace which is revealed through an individual's encounter with Christ's presence. ${ }^{20}$ 


\section{REFERENCES}

BARNET, Christopher B. Barnett, “'Should One Suffer Death for the Truth?' Kierkegaard, Erbaunngsliteratur, and the Imitation of Christ," Zeitschrift für neuere Theologiegeschichte, vol. 15, 2008, pp. 232-47

COCKAYNE, Joshua, 2017 'Contemporneity and communion: Kierkegaard on the personal presence of Christ' British Journal for the History of Philosophy, vol 25.1.

CONSTABLE, GILES, 1995 Three Studies in Medieval Religious and Social Thought, (Cambridge: Cambridge University Press)

DEWEY, Bradley, 1968: The New Obedience: Kierkegaard on Imitating Christ (Washington: Corpus Books), 1968

EVANS, C. Stephen, 1992: Passionate Reason: Making Sense of Kierkegaard's Philosophical Fragments (Indiana: Indiana University Press)

KAFTAŃSKI, Wojciech T, 2016: ‘The Socratic Dimension of Kierkegaard's Imitation’ The Heythrop Journal, doi: 10.1111/heyj.12330

KIERKEGAARD, Søren: Kierkegaard's Journals and Notebooks Volume 5, Journals NB6-NB10 Edited by Niels Jørgen Cappelørn, Alastair Hannay, David Kangas, Bruce. H Kirmmese, George Pattison, Joel D.S. Rasmussen, Vanessa Rumble and K. Brian Söderquist (Princeton: Princeton University Press), 2011

The Moment and Late Writings, Kierkegaard's Writings XXIII (Princeton: Princeton University Press) Translated by Howard V. Hong and Edna H. Hong, 2009

The Corsair Affair and Articles Related to the Writing, Kierkegaard's Writings, XIII (Princeton: Princeton University Press) Translated by Howard V. Hong and Edna H. Hong, 2009

Without Authority, Kierkegaard's Writings, XVIII. Translated by Howard V. Hong and Edna H. Hong. Princeton, NJ: Princeton University Press, 1997.

Works of Love Kierkegaard's Writings, XVI, (Princeton: Princeton University Press) Translated by Howard V. Hong and Edna H. Hong, 1995

Concluding Unscientific Postscript to Philosophical Fragments Vol. 1, Kierkegaard's Writings, XII.1 (Princeton: Princeton University Press) Translated by Howard V. Hong and Edna H. Hong, 1992

Practice in Christianity, Kierkegaard's Writings, XX (Princeton: Princeton University Press) Translated by Howard V. Hong and Edna H. Hong, 1991

For Self-Examination and Jude For Yourself, Kierkegaard's Writings, XXI (Princeton: Princeton University Press) Translated by Howard V. Hong and Edna H. Hong, 1990

Soren Kierkegaard's Journals and Papers, Volume 1, 1967 Edited and translated by Howard V. Hong and Edna H. Hong (Indiana: Indiana University Press) 
The Last Years, Joumals 1853-55 Edited and Translated by Ronald Gregor Smith, (London: Collins) 1965

LADNER, Gerhart B., 1959: The Idea of Reform: its Impact on Christian Thought and Action in the Age of the Fathers (Cambridge, Mass)

LECLERCQ, Jean (ed.) Sancti Bernardi opera, ed. Jean Leclercq, Charles H. Talbot, and HenriMarie Rochais (Rome 1957-77)

LUTHER, John. 'That These Words of Christ 'This is My Body,' etc., Still Stand Firm Against the Fanatics'. In Luther's Works, Word and Sacrament III, edited by Robert H. Fischer, 3-151. Philadelphia, PA: Fortress Press, 1961. Orginal date of publication 1527.

MULDER, Jack, Jr., 2008: 'Bernard of Clairvaux: Kierkegaard's Reception of the Last of the Fathers', in Kierkegaard and the Patristic and Medieval Traditions (Kierkegaard Research: Sources, Reception and Resources, vol. 4), ed. by Jon Stewart, Aldershot: Ashgate 2008. pp. 23-45; J

PATTISON, George, 2012: Kierkegaard and the Theology of the Nineteenth Century. Cambridge: Cambridge University Press

PEZ, Bernhard, 1721: Thesaurus anecdotorum novissimus seu, Veterum monumentorum, praecipue ecclesiasticorum, ex Germanicis potissimum bibliothecis adornata collectio recentissima, Augustae Vindelicorum \& Graecii, : sumptibus Philippi, Martini, \& Joannis Veith fratrum.

RASMUSSEN, Joel D.S, 2008: “Thomas à Kempis: Devotio Moderna and Kierkegaard's Critique of 'Bourgeois-Philistinism'," in Kierkegaard and the Patristic and Medieval Traditions, pp. 289299). In general, the author disregards scholarship on Kierkegaard's relation to medieval theology and spirituality

STAN, Leo, 2014: 'Imitation' in Jon Stewart, Steven M. Emmanuel and William McDonald (eds.), Kierkegaard's Concepts, Tome III, Envy to Incognito, Aldershot: Ashgate 2014 (Kierkegaard Research: Sources, Reception and Resources, vol. 15). pp. 203-7)

STOKES, Patrick, 2010: “See For Your Self”: Contemporaneity, Autopsy and Presence in Kierkegaard's Moral-Religious Psychology." British Journal for the History of Philosophy 18.2 (2010): 297-319.

THOMAS, à Kempis, 1952 The Imitation of Christ, Translated by Leo Sherley-Price (Harmondsworth: Penguin Books)

TINSLEY, Ernest J., 1957: 'The "imitation Christi” in the Mysticism of St Ignatius of Antioch', in Studia patrisrica, ed. Kurt Aland and F.L. Cross (Texte und Untersuchungen zur Geschichte der altchristlichen Literatur 63-4), Berlin II, 553-60

THULSTRUP, Marie Mikulová, 1962: 'Kierkegaard's Dialectic of Imitation', in Howard A. Johnson and Niels Thulstrup (eds.), A Kierkegaard Critique: An International Selection of Essays Interpreting Kierkegaard, New York: Harper 1962, pp. 266-85

TORRANCE, Andrew B., 2016: The Freedom to Become a Christian, London: Bloomsbury 
WESTPHAL, Merold, 2014: Kierkegaard's Concept of Faith (Michigan/ Cambridge: William B. Eerdmans Publishing Company), Kierkegaard as a Christian Thinker Series

${ }^{1}$ Within this latter part of Kierkegaard's writings, the most detailed discussions of imitation are found in Practice in Christianity (1850), Judge for Yourself! (1851-2, published posthumously), For SelfExamination (1851), along with many of his post 1849 journal entries.

${ }^{2}$ I use the International Kierkegaard Commentary system of abbreviation to refer to the Kierkegaard's

Writings series throughout, and refer to the following works:

$\mathrm{CD}=$ Christian Discourses

CUP $=$ Concluding Unscientific Postscript to 'Philosophical Fragments', vol. 1

$\mathrm{FSE}=$ For Self Examination and Judge for Yourself

JFT $=$ Judge for Yourself!

$\mathrm{JP}=$ Journals and Papers

$\mathrm{PC}=$ Practice in Christianity

$\mathrm{PF}=$ Philosophical Fragments and Johannes Climacus

$\mathrm{TM}=$ The Moment and Late Writings

WA $=$ Without Authority

$\mathrm{WL}=$ Works of Love

${ }^{3}$ Concluding Unscientific Postscript ends with a request from Kierkegaard to attribute the preceding discussion to the pseudonym 'Johannes Climacus' and not to himself (CUP, 225-30). I follow Kierkegaard's request here and refer to Anti-Climacus when discussing Practice in Christianity. Nevertheless, given the similarities of the account of imitation put forward by Anti-Climacus with the account in Judge for Yourself! (which is authored by Kierkegaard rather than a pseudonym), I sometimes refer to 'Kierkegaard's account of imitation' even when including aspects of Anti-Climacus's account.

${ }^{4}$ Anti-Climacus's discussion of imitation arises out of his reflection on John 12:32 in which Christ states that 'And I, when I am lifted up from the earth, will draw all people to myself.' (NRSV)

${ }^{5}$ See, for instance Stan 2016, Thulstrup 1962, Barnnet 2008, Kaftański 2016, Dewey 1968.

${ }^{6}$ Kierkegaard is clearly aware of other accounts of imitation-he explicitly refers to Luther and, according to Bradley Dewey, Kierkegaard's library contained two editions of The Imitation of Christ, along with other ascetic works by Johannes Tauler and William Law $(1968,112)$. However, Kierkegeaard avoids using the Latin imitatio Christi, which would help to situate his discussion of imitation alongside those in the history of Christian theology (Dewey, 1968, 119). Instead, as Dewey draws attention to, Kierkegaard uses the more imprecise Danish word 'efterfølgelese', from the root 'efterfølge', which could be understood as meaning 'to follow', 'to obey', 'to model oneself on a given example' or 'to take advice' (Dewey, 1968, 119-20).

Kierkegaard never explicitly indicates which sense of 'efterfølgelese' he wishes to be understood. Despite this, most translators render 'efterfølgelese' as 'imitate'. It is plausible to think that this imprecision is due to Kierkegaard's views on direct and indirect communication, and his claim that he is one 'without authority' (FSE, 17).

${ }^{7}$ One of the clearest accounts of the development of Kierkegaard's thinking on imitation can be found in Marie Thulstrup's article 'Kierkegaard's Dialectic of Imitation'. As I have done here, Thulstrup distinguishes the outward imitation of the monastic, scholarly or priestly lifestyle from the true imitation of following Christ inwardly as a single individual. She notes that,

Kierkegaard's greatest objection to the mediaeval mind is that at the same time it broke with the world it also fled from the world; thereby it avoided persecution and, on the contrary, gained recognition and respect [...] The task of a Christian (in the strongest 
sense of the term) is to renounce the world and at the same time to remain in it - and be sacrificed. $(1962,273)$

\footnotetext{
${ }^{8}$ Pre ninth-century theologians do not give much attention to our imitation of the historical Christ. Instead, the early Church Fathers tend rather to emphasise Christ's divinity and the theological implications of this for imitating Christ. In particular, imitation is often discussed in connection with the concept of deification in these early texts. Ignatius of Antioch (35-98 CE), for example, according to EJ Tinsley, claims that the imitation of Christ was not a 'literal mimicry or emulation', but 'a process of being conformed to the true image of God which is the Son Himself who becomes incarnate for our restoration' $(1957,560)$. To take a later example, Gregory of Nyssa (335-395 CE) describes the imitation of Christ as a means of restoring the likeness of God in us through the imitation of Christ's virtues. See, Constable (1995, 153-70), and Ladner $(1959,90)$ for more details on pre ninth-century understandings of imitation.

${ }^{9}$ For a more detailed account of Kierkegaard's discussion of Bernard, see Mulder Jr., 2008

${ }^{10}$ Dewey, in his discussion of this conception of imitation, does not specify the sources of this interpretation but merely summarises what he calls 'facsimile imitation' as the 'attempt to shape his life in literal conformity to the life of Jesus as recorded in the New Testament' $(1968,105)$ ${ }^{11}$ Here Kierkegaard seems to be directly quoting from 1 Peter 2:21.

${ }^{12}$ As Mulder summarises the key point of divergence between Bernard and Kierkegaard,

From a Kierkegaardian point of view, to think that outward acts are simply commensurable with the inward passion of faith is an error. While Bernard does indeed [...] embrace a Church of both lay and religious followers of Christ, he nonetheless does believe that the monastic or religious vocation is the best way to live a life devoted to Christian discipleship. $(2008,41)$
}

${ }^{13}$ This is an earlier translation of the Hongs's translation of Journals and Paper, but Smith's use of 'lazy imitation' helps to stress the point here.

${ }^{14}$ See Rasmussen 2008 for a discussion of Thomas's influence on Kierkegaard's writing about imitation.

${ }^{15}$ Christopher B. Barnett (2008) explores the comparison between Kierkegaardian imitation and Thomas (along with other medieval thinkers such as Johannes Tauler) in considerably more depth than there is space for here.

${ }^{16}$ As Rasmussen notes, none of Kierkegaard's direct references to Thomas in the journals refer explicitly to imitation and Kierkegaard never attributes the influence of Thomas's thought for his own writings.

${ }^{17}$ Thulstrup also draws this connection between contemporaneity and imitation, albeit in different terms:

The distinctive mark of imitation is not the act of being a bloody sacrifice, but an inward suffering, a bloodless martyrdom, which because of its isolation is the most dreadful of all. This is the suffering encountered in the process of "dying unto the world," a theme earlier stressed, for example in Works of Love; it must now be seen under the category of contemporaneity with Christ. (1962, 269-70)

${ }^{18}$ Again, it is unclear whether Stokes and Westphal refer to the same concept here, even though there are similarities in their claims. Westphal's argument is contained to a very small discussion of contemporaneity in Practice in Christianity, whereas Stokes's proposal is more ambitious-he argues that there is some consistency in how Kierkegaard uses the term. We cannot assume that 
Kierkegaard speaks in a single voice throughout the corpus, and a more focused discussion of contemporaneity will be of some help, here.

${ }^{19}$ With thanks to an anonymous reviewer for this suggestion.

${ }^{20}$ I would like to thank David Efird, Jack Warman, along with an anonymous referee for helpful feedback on earlier drafts of this paper. I also thank the participants in the Collegio Ghislieri Graduate Conference in the History of Philosophy 2015 for their questions and comments on an earlier draft of this paper. With many thanks to the Templeton Religious Trust for providing funding during the revision of this paper. 